FOLIA POMERANAE UNIVERSITATIS TECHNOLOGIAE STETINENSIS

Folia Pomer. Univ. Technol. Stetin., Agric., Aliment., Pisc., Zootech. 2019, 348(49)1, 103-110

Daniel POLASIK, Eva Maria KAMIONKA', Mirosław TYRA', Dagmara ZAGROBELNY, Grzegorz ŻAK², Arkadiusz TERMAN

\title{
FTO AND PLIN2 GENES POLYMORPHISM IN RELATION TO GROWTH TRAITS OF PIGS
}

\author{
Department of Genetics and Animal Breeding, West Pomeranian University of Technology, Szczecin, \\ Poland \\ ${ }^{1}$ Department of General, Visceral and Transplantation Surgery, University Hospital Heidelberg, \\ Heidelberg, Germany \\ 2Department of Animal Genetics and Breeding, National Research Institute of Animal Production, \\ Balice, Poland
}

\begin{abstract}
FTO and PLIN2 genes are considered as a markers for fat-related traits in pigs. However, high expression of these genes in muscle tissues and earlier studies suggest, that they can be also associated with growth. Therefore the aim of this study was to analyze polymorphism in FTO (g.400C > G) and PLIN2 (g.98G > A) genes in relation to growth traits in pigs. The study were conducted on 578 sows including following breeds: Duroc, Hampshire, Polish Landrace, Pietrain, Puławska and Polish Large White. FTO and PLIN2 genes polymorphism was determined by use PCR-RFLP and ACRS-PCR methods respectively. Association analysis was performed for Polish Landrace, Puławska and Polish Large White separately and for joined group of 6 breeds. The results show that FTO genotypes were related only to test daily gain in Polish Large White pigs $(p<0.05)$. PLIN2 gene variants, however were associated with test daily gain in Polish Landrace, Puławska ( $p<0.01$ ) and joined group $(p<0.05)$, average daily gain in Puławska $(p<0.01)$, feed:gain ratio in joined group $(p<0.05)$ and age at slaughter and number of days on test in Puławska $(p<0.01)$ and joined group ( $p<0.01$ and $p<0.05$ respectively). Obtained results show that PLIN2 gene is more related to growth traits in pigs than FTO, but needs further analysis and explanation.
\end{abstract}

Key words: FTO, PLIN2, polymorphism, growth traits, pigs.

\section{INTRODUCTION}

One of the method for QTL (quantitative trait loci) identification is evaluation the effect of the polymorphism in genes (known as candidate genes) on the level of certain quantitative traits in different breeds and lines of pigs. This analysis usually involves genes whose product (protein) is known to be involved in physiological processes associated with a given production trait (Żak and Pieszka 2009).

Fat mass and obesity associated gene (FTO) plays an important role in controlling of appetite and energy consumption in human and mice. FTO gene expression is significantly highest $(p<0.05)$ in pig backfat, when compare to other tissues, whereas in $m$. longissimus dorsi shows the second highest level $(p<0.05)$ (Fu et al. 2013). Although FTO gene has been proposed as a marker for fat deposition (Fontanesi et al. 2009) it may be also

Corresponding author: Daniel Polasik, Department of Genetics and Animal Breeding, West Pomeranian University of Technology, Szczecin, Piastów 45, 70-311 Szczecin, Poland, e-mail: daniel.polasik@zut.edu.pl 
considered as a marker for growth traits in pigs because its high expression in muscles. It was proved by Fan et al (2009) who analyzed single nucleotide polymorphism (SNP) detected in exon 3 (g.400C $>\mathrm{G}$ ) of porcine FTO gene. The study showed that individual genotypes were significantly associated with average daily gain on test and total lipid percentage in muscle $(P<0.01)$ of Berkshire $\times$ Yorkshire pigs. Later it was also demonstrated that g.400C > G variants influence some carcass and fat-related and growth traits including average daily gain, feed conversion ratio and feed consumption (Dvořáková et al. 2012).

Perilipin 2 (PLIN2) stimulates long chain fatty acid uptake and regulates metabolism of intracellular lipid droplets (Gao and Serrero 1999; Conte et al. 2016). Expression analysis showed the presence of PLIN2 transcripts in all seven investigated pig tissues with high expression found in adipose tissue and skeletal muscle (Davoli et al. 2011). Other study, that covered fat-type and lean-type pigs indicated that PLIN2 was expressed similarly in backfat of both groups, however PLIN2 transcripts were more abundant in muscle of fat-type than in that of lean-type pigs (Tempfli et al. 2016). Similarly to FTO gene PLIN2 has been proposed as a marker for fat-related traits, especially intramuscular content (Yang et al. 2017), but mentioned expression studies indicate that it could be also take into consideration as a marker for growth traits in pigs. This hypothesis is supported by results of Davoli et al. (2011) who detected SNP in porcine 3'-untranslated region (UTR) of PLIN2 gene (g.98G > A). Association analysis showed that its different variants are related $(P<0.01)$ to average daily gain, feed conversion ratio, lean cuts and ham weight estimated breeding values in Duroc pigs. Further study also confirmed that PLIN2 SNP is associated with early growth rate and carcass length in the same breed (Gol et al. 2016).

Because FTO and PLIN2 genes are promising markers for growth traits, the aim of this study was to analyze their variants ( $\mathrm{g} .400 \mathrm{C}>\mathrm{G}$ and g.98G $>$ A respectively) in relation growth traits of pigs reared in Poland.

\section{MATERIAL AND METHODS}

The study were performed on 578 sows that belong to following breeds: Duroc $(n=14)$, Hampshire $(n=7)$, Polish Landrace $(n=269)$, Pietrain $(n=31)$, Puławska $(n=68)$ and Polish Large White $(n=189)$. Pigs were kept in three Pig Test Stations (SKURTCh) of the National Research Institute of Animal Production, located in Chorzelów, Pawłowice and Mełno (Poland). Conditions of rearing and feeding were unified for all animals. Pigs were introduced to stations at the age of 12 weeks and fed ad libitum according to SKURTCh scheme till reach $100( \pm 3) \mathrm{kg}$ weight of body (Różycki and Tyra 2009). After feeding period pigs were slaughtered and tissues for DNA analysis were collected.

During the test following growth traits were estimated for each pig: test daily gain (TDG), average daily gain (ADG), feed:gain ratio (FCR), daily feed intake (DFI), age at slaughter (AS) and number of days on test (NDT). TDG was calculated by subtracting off-test weight and on-test weight, then dividing by NDT.

Genomic DNA was isolated from collected tissues using ReliaPrep ${ }^{\text {TM }}$ gDNA Tissue Miniprep System (Promega, USA) and Genomic Mini (A\&A Biotechnology, Gdynia, Poland) kits. 
Polymorphism of porcine FTO gene ( $\mathrm{g} .400 \mathrm{C}>\mathrm{G}$ ) was detected by use of PCR-RFLP method. Following pair of primers for PCR were designed based on FM244720.1 sequence: F 5'-GCC GGT GTG TAT AGG TCC AG-3', R 5'-GGA TCC ATG AAG CTC AAC AAA3' (Primer3Plus; Untergasser et al. 2012). PCR mixes for FTO and PLIN2 genes were prepared in the same way and contains: GoTaq ${ }^{\circledR}$ Master Mix (Promega, USA), 10pmol of each primer, 40-70ng of DNA and PCR grade water fill up to $10 \mu \mathrm{l}$. For FTO gene, following PCR conditions were applied: $95^{\circ} \mathrm{C} / 5 \mathrm{~min}, 30$ cycles of $95^{\circ} \mathrm{C} / 40 \mathrm{~s}, 54^{\circ} \mathrm{C} / 40 \mathrm{~s}, 72^{\circ} \mathrm{C} / 40 \mathrm{~s}$ and $72^{\circ} \mathrm{C} / 5 \mathrm{~min}$. After PCR, amplicons were digested overnight at $37^{\circ} \mathrm{C}$ by $R$ sal restriction enzyme (Thermo Scientific, USA) and separated in $2.5 \%$ agarose gels stained with ethidium bromide.

Polymorphism in pig PLIN2 gene ( $.98 \mathrm{G}>\mathrm{A}$ ) was detected by means of ACRS-PCR method. Primers for PCR were designed manually based on GU461317.1 sequence and its properties were estimated by use of OligoAnalyzer 3.1 software (Integrated DNA Technologies, USA): F 5'-TTT TGC CTC TGT TGC CAC TGT TTG CCA GCT-3', R 5'-GTG AGA CAA ACC AGT GCT GAG GCC-3'. Cycling conditions were as follows: $95^{\circ} \mathrm{C} / 5 \mathrm{~min}$, 32 cycles of $95^{\circ} \mathrm{C} / 1 \mathrm{~min}, 63^{\circ} \mathrm{C} / 1 \mathrm{~min}, 72^{\circ} \mathrm{C} / 2 \mathrm{~min}$ and $72^{\circ} \mathrm{C} / 5 \mathrm{~min}$. Obtained amplicons were digested overnight at $37^{\circ} \mathrm{C}$ by Pvull restriction enzyme (Thermo Scientific, USA). Next, restriction fragments were separated in $3 \%$ agarose gels stained with ethidium bromide.

Analyzed growth and feeding traits of pigs were assessed in a fixed model using the least squares method of the General Linear Model procedure in SAS/STAT software (SAS Institute Inc., USA). For association study the following statistical model was used:

$$
Y_{i j k}=\mu+b_{i}+g_{j}+(b g)_{i j}+e_{i j k}
$$

where:

$\mathrm{Y}_{\mathrm{ijk}}$ - the observation;

$\mu$ - the overall mean;

$b_{i}-$ the fixed effect of $i$ breed;

$\mathrm{g}_{\mathrm{j}}$ - the fixed effect of $\mathrm{j}$ genotype group of FTO or PLIN2 gene;

$(\mathrm{bg})_{\mathrm{ij}}$ - interaction between $\mathrm{g}_{\mathrm{j}}$ genotype group and $\mathrm{b}_{\mathrm{i}}$ breed (when significant);

$\mathrm{e}_{\mathrm{ijk}}$ - random residual error.

Analyses were conducted for Polish Landrace, Polish Large White and Puławska breeds separately and for all pigs together (6 breeds).

\section{RESULTS AND DISCUSSION}

PCR-RFLP method allowed to determine FTO variants based on following lengths of restriction fragments: $C C-123 \mathrm{bp}, C G-123,92,31 \mathrm{bp}, G G-92,31 \mathrm{bp}$ (Fig. 1). All genotypes and alleles of FTO gene were present in studied breeds, except Hampshire, where GG genotype was absent. $C$ allele was predominant in all breeds, excluding Duroc.

Proposed method - ACRS-PCR, successfully enabled to determine PLIN2 variants based on following restriction fragment lengths: $A A-127 \mathrm{bp}, A G-127,99,28 \mathrm{bp}, G G-99$, 28bp (Fig. 2). In analyzed breeds, $A A$ genotype was present only in half of them (Duroc, Hampshire and Puławska). In Duroc it reached highest frequency, however GG genotype was absent in this breed. In other breeds $G G$ genotype and $G$ allele were predominant. 


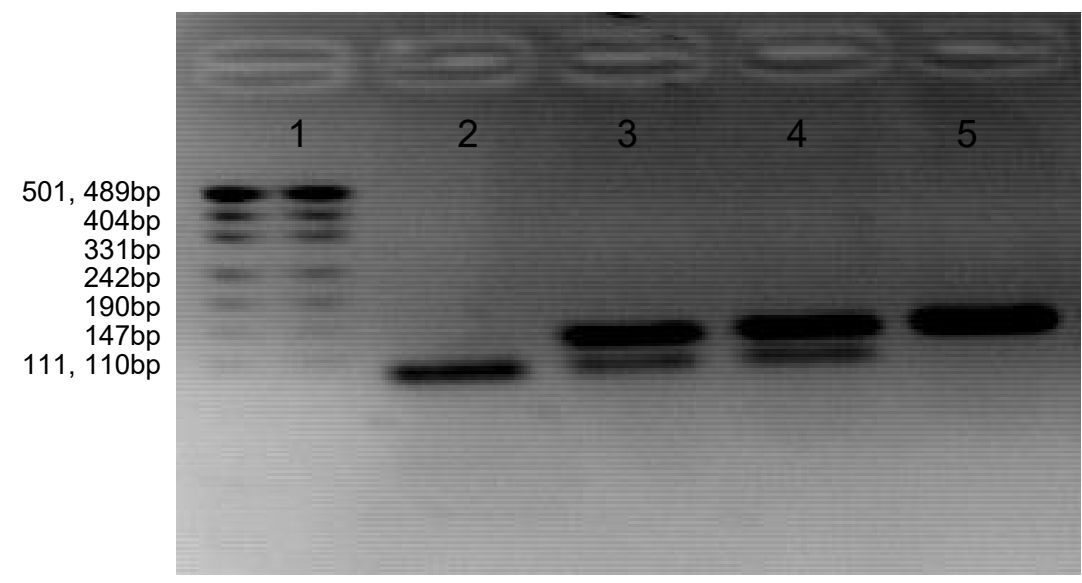

Fig. 1. FTO genotype determination by means of electrophoresis in $2.5 \%$ agarose gel. Lane 1 pUC19/Mspl DNA marker (Thermo Scientific, USA), lane 2-GG genotype, lanes 3, 4-CG genotype, lane $5-C C$ genotype. Band of $31 \mathrm{bp}$ is not visible

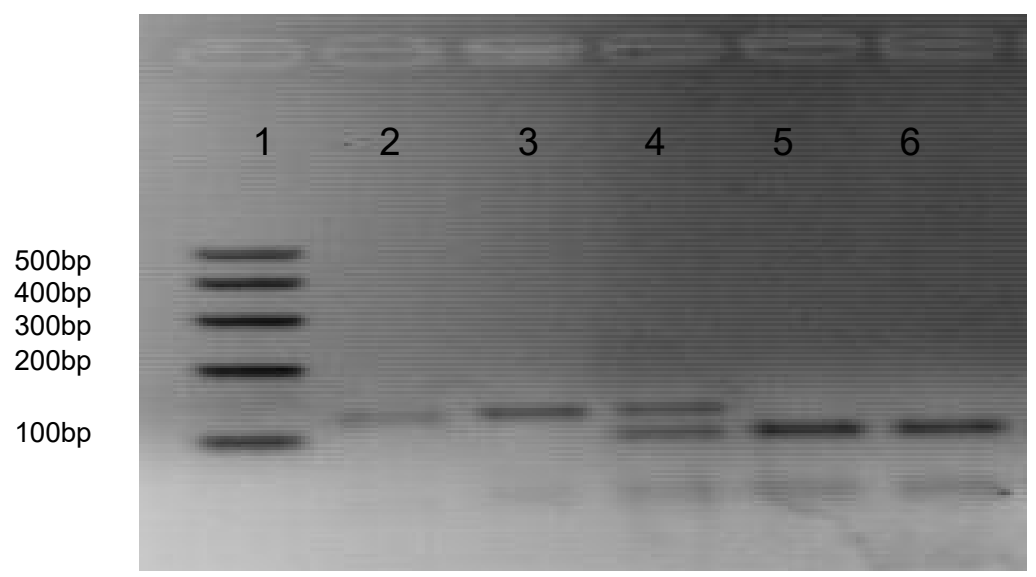

Fig. 2. PLIN2 genotype determination by means of electrophoresis in $3 \%$ agarose gel. Lane 1 - DNA marker M100-500 (DNA Gdańsk, Poland), lanes 2, 3 - AA genotype, lane $4-A G$ genotype, lanes 5, $6-G G$ genotype. Band of $28 \mathrm{bp}$ is not good visible

Association between FTO genotypes and growth traits in analyzed pigs is presented in Table 1. We found that different variants of this gene were correlated only with test daily gain in Polish Large White. Sows with CC genotype were characterized by highest values of this trait in relation to those with $G G(p \leq 0.05)$. The same tendency was observed for joined group but was not confirmed statistically. Other studies, however shown that GG genotype is favorable for average daily gain in Pietrain $\times$ (Czech Landrace $\times$ Czech Large White) $(p=0.02)$ and Meishan $\times$ Pietrain $(p=0.04)$ crossbreeds as well as in joined group including 7 crossbreeds and one pure breed $(p=0.02)$ (Fan et al. 2009; Dvořáková et al. 2012). In our study we found, however that $C C$ or $C G$ genotype was associated with highest values of this trait but differences were not significant. In Meishan $\times$ Pietrain, Berkshire $\times$ Yorkshire and joined group, CG genotype was also correlated with highest feed conversion ratio ( $p=0.008$, $p=0.04, p=0.003$ respectively), whereas in our study we observed this non-significant tendency for homozygous genotypes. 
Table 1. Association between FTO gene polymorphism and growth traits in different pig breeds and in joined group (LSM \pm SE)

\begin{tabular}{lccccc}
\hline \multicolumn{1}{c}{ Trait } & Genotype & $\begin{array}{c}\text { Polish } \\
\text { Landrace } \\
(\mathrm{n}=269)\end{array}$ & $\begin{array}{c}\text { Polish Large } \\
\text { White } \\
(\mathrm{n}=189)\end{array}$ & $\begin{array}{c}\text { Puławska } \\
(\mathrm{n}=68)\end{array}$ & $\begin{array}{c}\text { Joined group } \\
(\mathrm{n}=578)\end{array}$ \\
\hline \multirow{3}{*}{ Test daily gain [g/day] } & $C C$ & $909 \pm 26.3$ & $900 \pm 17.09^{\mathrm{a}}$ & $804 \pm 14.29$ & $863 \pm 12.32$ \\
& $C G$ & $910 \pm 24.7$ & $880 \pm 17.80$ & $811 \pm 15.39$ & $863 \pm 12.41$ \\
& $G G$ & $904 \pm 27.9$ & $875 \pm 32.4 \mathrm{a}$ & $814 \pm 28.1$ & $853 \pm 16.24$ \\
\hline \multirow{3}{*}{ Average daily gain [g/day] } & $C C$ & $617 \pm 19.2$ & $592 \pm 8.3$ & $549 \pm 10.6$ & $577 \pm 8.0$ \\
& $C G$ & $620 \pm 18.0$ & $584 \pm 8.6$ & $542 \pm 11.4$ & $582 \pm 8.0$ \\
& $G G$ & $619 \pm 20.4$ & $583 \pm 15.7$ & $548 \pm 20.8$ & $576 \pm 10.5$ \\
\hline \multirow{3}{*}{ Feed:gain ratio [kg] } & $C C$ & $2.641 \pm 0.069$ & $2.669 \pm 0.034$ & $2.794 \pm 0.037$ & $2.677 \pm 0.031$ \\
& $C G$ & $2.645 \pm 0.065$ & $2.714 \pm 0.035$ & $2.788 \pm 0.040$ & $2.690 \pm 0.031$ \\
& $G G$ & $2.648 \pm 0.074$ & $2.747 \pm 0.064$ & $2.765 \pm 0.072$ & $2.695 \pm 0.041$ \\
\hline \multirow{2}{*}{ Daily feed intake [kg] } & $C C$ & $2.389 \pm 0.071$ & $2.389 \pm 0.042$ & $2.237 \pm 0.027$ & $2.295 \pm 0.031$ \\
& $C G$ & $2.418 \pm 0.066$ & $2.381 \pm 0.043$ & $2.280 \pm 0.029$ & $2.308 \pm 0.032$ \\
& $G G$ & $2.382 \pm 0.075$ & $2.386 \pm 0.079$ & $2.245 \pm 0.053$ & $2.284 \pm 0.042$ \\
\hline \multirow{2}{*}{ Age at slaughter [days] } & $C C$ & $173 \pm 5.7$ & $175 \pm 2.5$ & $185 \pm 3.5$ & $181 \pm 2.4$ \\
& $C G$ & $171 \pm 5.4$ & $177 \pm 2.6$ & $186 \pm 3.8$ & $180 \pm 2.4$ \\
\hline \multirow{2}{*}{ Number of days on test } & $G G$ & $170 \pm 6.1$ & $177 \pm 4.7$ & $185 \pm 6.9$ & $181 \pm 3.2$ \\
\hline [days] & $C C$ & $83.2 \pm 2.459$ & $81.9 \pm 1.481$ & $88.3 \pm 1.672$ & $86.2 \pm 1.147$ \\
\hline
\end{tabular}

$\mathrm{n}-$ the number of animals analyzed in given group; values marked with the same letter differ statistically at $p \leq 0.05\left({ }^{a}\right)$

Table 2 presents results of association study for PLIN2 polymorphism. In Polish Landrace we found that PLIN2 variants were associated with test daily gain ( $p \leq 0.01$ ), whereas in Puławska with test daily gain, average daily gain, age at slaughter and number of days on test ( $p \leq 0.01$ ). In the first breed $A G$ genotype was associated with highest test daily gain, while $G G$ in the second. These differences may results from the high genetic distance between mentioned breeds. Puławska is polish native breed, under conservation breeding, classified between meat and meat fat type of utility. Polish Landrace, however is commercial breed that represents meat type. It is hard to discuss obtained results with others because of presence only two genotypes in breeds under association study. Davoli et al. (2011) shown that PLIN2 SNP is correlated with average daily gain, feed conversion ratio, lean cuts and hams weight estimated breeding values. In Italian Duroc pigs, $A A$ genotype was characterized by highest average daily gain ( $p=0.003$ ), whereas $G G$ genotype by highest feed conversion ratio ( $p=0.002$ ). In our study we found statistically significant association with average daily gain only in Puławska breed ( $p \leq 0.01$ ), where GG genotypes was favorable for this trait. Further studies shown that $A$ allele influence only early growth (up to 120 day) in Duroc breed (Gol et al. 2016). In our study average daily gain was measured since introduction of sows to stations at the age of 12 weeks till slaughter (174-202 days), so only partially covered early growth. Similarly to Davoli et al. (2011) we noticed tendency that GG genotype is correlated with highest values of feed:gain ratio in each breed and joined group, but it was confirmed only in all animals together $(p \leq 0.05)$. In Puławska breed we found that GG genotype was associated with better gains, what was naturally correlated with lowest age of slaughter and number of days on test $(p \leq 0.01)$. In the joined group reverse tendency was noticed. Highest test daily gain $(p \leq 0.05)$ and lowest age of slaughter 
$(p \leq 0.01)$ and number of days on test $(p \leq 0.05)$ were observed in animals with $A A$ genotype. This tendency may result from the presence of $A A$ genotype in joined group or/and from different utility types of analyzed pigs.

Table 2. Association between PLIN2 polymorphism and growth traits in different pig breeds and in joined group (LSM $\pm \mathrm{SE})$

\begin{tabular}{|c|c|c|c|c|c|}
\hline Trait & Genotype & $\begin{array}{c}\text { Polish } \\
\text { Landrace } \\
(\mathrm{n}=269) \\
\end{array}$ & $\begin{array}{c}\text { Polish Large } \\
\text { White } \\
(n=189) \\
\end{array}$ & $\begin{array}{l}\text { Puławska } \\
(\mathrm{n}=68)\end{array}$ & $\begin{array}{l}\text { Joined group } \\
\quad(n=578)\end{array}$ \\
\hline Test daily gain [g/day] & $\begin{array}{l}A A \\
A G \\
G G\end{array}$ & $\begin{array}{c}- \\
938 \pm 30.8^{A} \\
915 \pm 24.4^{A}\end{array}$ & $\begin{array}{c}\overline{2} \\
886 \pm 29.8 \\
892 \pm 15.8\end{array}$ & $\begin{array}{c}-\overline{-} \\
761 \pm 38.8^{A} \\
817 \pm 11.0^{A}\end{array}$ & $\begin{array}{l}896 \pm 41.4^{\mathrm{ab}} \\
862 \pm 16.8^{\mathrm{b}} \\
858 \pm 13.1^{\mathrm{a}}\end{array}$ \\
\hline Average daily gain [g/day] & $\begin{array}{l}A A \\
A G \\
G G \\
\end{array}$ & $\begin{array}{c}- \\
605 \pm 22.4 \\
608 \pm 17.8 \\
\end{array}$ & \begin{tabular}{l}
\multicolumn{1}{c}{-} \\
$579 \pm 14.4$ \\
$589 \pm 7.6$ \\
\end{tabular} & \begin{tabular}{c}
\multicolumn{1}{c}{-} \\
$505 \pm 28.8^{A}$ \\
$564 \pm 8.2^{A}$ \\
\end{tabular} & $\begin{array}{l}580 \pm 26.7 \\
562 \pm 10.8 \\
583 \pm 8.5 \\
\end{array}$ \\
\hline Feed:gain ratio $[\mathrm{kg}]$ & $\begin{array}{l}A A \\
A G \\
G G \\
\end{array}$ & $\begin{array}{c}- \\
2.644 \pm 0.064 \\
2.650 \pm 0.081\end{array}$ & $\begin{array}{c}- \\
2.688 \pm 0.031 \\
2.705 \pm 0.059 \\
\end{array}$ & $\begin{array}{c}- \\
2.785 \pm 0.100 \\
2.791 \pm 0.029 \\
\end{array}$ & $\begin{array}{l}2.599 \pm 0.104^{\mathrm{ab}} \\
2.693 \pm 0.033^{\mathrm{a}} \\
2.702 \pm 0.042^{\mathrm{b}} \\
\end{array}$ \\
\hline Daily feed intake [kg] & $\begin{array}{l}A A \\
A G \\
G G \\
\end{array}$ & $\begin{array}{c}- \\
2.478 \pm 0.083 \\
2.405 \pm 0.066\end{array}$ & $\begin{array}{c}- \\
2.357 \pm 0.072 \\
2.388 \pm 0.038\end{array}$ & $\begin{array}{c}- \\
2.091 \pm 0.072 \\
2.272 \pm 0.020 \\
\end{array}$ & $\begin{array}{l}2.321 \pm 0.106 \\
2.312 \pm 0.043 \\
2.294 \pm 0.034\end{array}$ \\
\hline Age at slaughter [days] & $\begin{array}{l}A A \\
A G \\
G G\end{array}$ & $\begin{array}{c}- \\
174 \pm 6.7 \\
174 \pm 5.3\end{array}$ & $\begin{array}{c}- \\
179 \pm 4.3 \\
177 \pm 2.3 \\
\end{array}$ & $\begin{array}{c}- \\
202 \pm 9.5^{\mathrm{A}} \\
179 \pm 2.7^{\mathrm{A}}\end{array}$ & $\begin{array}{l}181 \pm 8.0^{A b} \\
186 \pm 3.2^{b} \\
189 \pm 2.5^{A}\end{array}$ \\
\hline $\begin{array}{l}\text { Number of days on test } \\
\text { [days] }\end{array}$ & $\begin{array}{l}A A \\
A G \\
G G\end{array}$ & $\begin{array}{c}- \\
81.1 \pm 2.877 \\
82.7 \pm 2.279\end{array}$ & $\begin{array}{c}- \\
84.5 \pm 2.578 \\
82.4 \pm 1.367\end{array}$ & $\begin{array}{c}- \\
96.1 \pm 4.476^{\mathrm{A}} \\
86.3 \pm 1.274^{\mathrm{A}}\end{array}$ & $\begin{array}{l}83.6 \pm 3.854^{a b} \\
86.10 \pm 1.560^{b} \\
86.3 \pm 1.226^{a}\end{array}$ \\
\hline
\end{tabular}

$\mathrm{n}$ - the number of animals analyzed in given group; values marked with the same letter differ statistically at $p \leq 0.05\left({ }^{a b}\right)$ or $p \leq 0.01\left(^{A}\right)$.

\section{CONCLUSIONS}

In our study we have tested hypothesis that FTO and PLIN2 genes polymorphism may be associated with growth traits in pigs. Analysis were performed on three breeds separately and joined group that included six breeds $(n=578)$. Results shown that FTO variants were associated only with one trait (test daily gain) in Polish Large White ( $p \leq 0.05)$, while PLIN2 variants in most of analyzed traits. PLIN2 genotypes were correlated with test daily gain, average daily gain, feed:gain ratio, age of slaughter and number of days on test ( $p \leq 0.05$ or $p \leq 0.05)$ in individual pig breeds and joined population. We observed also reverse distribution of the growth traits regarding to PLIN2 genotypes in Puławska breed and joined group. To conclude, PLIN2 gene seems to be more promising marker for growth traits in pigs, but needs further studies.

\section{REFERENCES}

Conte M., Franceschi C., Sandri M., Salvioli S. 2016. Perilipin 2 and age-related metabolic diseases: A New Perspective. Trends Endocrinol. Metab. 27, 893-903.

Davoli R., Gandolfi G., Braglia S., Comella M., Zambonelli P., Buttazzoni L., Russo V. 2011. New SNP of the porcine perilipin 2 (PLIN2) gene, association with carcass traits and expression analysis in skeletal muscle. Mol. Biol. Rep. 38, 1575-1583. 
Dvořáková V., Bartenschlager H., Stratil A., Horák P., Stupka R., Cítek J., SprysI M., Hrdlicová A., Geldermann H. 2012. Association between polymorphism in the FTO gene and growth and carcass traits in pig crosses. Genet. Sel. Evol. 44, 13.

Fontanesi L., Scotti E., Buttazzoni L., Davoli R., Russo V. 2009. The porcine fat mass and obesity associated (FTO) gene is associated with fat deposition in Italian Duroc pigs. Anim. Genet. 40, 90-93.

Fan B., Du Z.Q., Rothschild M.F. 2009. The fat mass and obesity-associated (FTO) gene is associated with intramuscular fat content and growth rate in the pig. Anim. Biotechnol. 20, 58-70.

Fu Y., Li L., Ren S. 2013. Effect of FTO expression and polymorphism on fat deposition in Suzhong pigs. Asian-Australas. J. Anim. Sci. 26, 1365-1373.

Gao J., Serrero G. 1999. Adipose differentiation related protein (ADRP) expressed in transfected COS-7 cells selectively stimulates long chain fatty acid uptake. J. Biol. Chem. 274, 16825-16830.

Gol S., Ros-Freixedes R., Zambonelli P., Tor M., Pena R.N., Braglia S., Zappaterra M., Estany J., Davoli R. 2016. Relationship between perilipin genes polymorphisms and growth, carcass and meat quality traits in pigs. J. Anim. Breed. Genet. 133, 24-30.

Różycki M., Tyra M. 2009. Metodyka oceny wartości tucznej i rzeźnej świń przeprowadzana w stacjach kontroli użytkowości rzeźnej trzody chlewnej (SKURTCh). Kraków, Wydaw. IZ, 94-117.

Tempfli K., Kiss B., Szalai K., Simon Z., Pongrácz L., Papp Á.B. 2016. Differential expression of six genes in fat-type Hungarian Mangalica and other pigs. Arch. Anim. Breed. 59, 259-265.

Untergasser A., Cutcutache I., Koressaar T., Ye J., Faircloth B.C., Remm M., Rozen S.G. 2012. Primer3--new capabilities and interfaces. Nucleic. Acids Res. 40, e115.

Yang M., Dong K., Shu X., Li W., Huang Y., Pan H., Zhao S. 2017. Cloning of perilipin 2 gene and investigating its expression level in porcine longissimus muscle. J. Vet. Sci. Ann. Husb. 5, 1-9.

Żak G., Pieszka M. 2009. Improving pork quality through genetics and nutrition. Ann. Anim. Sci. 9, 327-338.

\title{
POLIMORFIZM GENÓW FTO I PLIN2 W ODNIESIENIU DO CECH WZROSTU ŚWIŃ
}

\begin{abstract}
Streszczenie. Geny FTO i PLIN2 są rozważane jako markery cech związanych z cechami otłuszczenia świń. Wysoka ekspresja tych genów w tkance mięśniowej i poprzednie badania sugerują, że mogą być one powiązane również ze wzrostem. W związku z powyższym celem niniejszych badań była analiza polimorfizmu w genach FTO (g.400C > G) i PLIN2 (g.98G > A), w odniesieniu do cech wzrostu świń. Badania przeprowadzono na 578 lochach ras: duroc, hampshire, polska biała zwisłoucha, pietrain, puławska i wielka biała polska. Polimorfizm genów FTO i PLIN2 został określony za pomocą metod PCR-RFLP i ACRS-PCR. Analizy zależności wykonano oddzielnie dla ras polska biała zwisłoucha, puławska i wielka biała polska oraz dla grupy łączącej 6 ras. Wyniki wykazały, że genotypy FTO były powiązane tylko z przyrostem dziennym świń rasy polska biała zwisłoucha $(p<0,05)$. Warianty genów PLIN2 były natomiast związane z przyrostem dziennym świń ras polska biała zwisłoucha, puławska $(p<0,01)$ i w grupie łączącej 6 ras $(p<0,01)$, ze średnim przyrostem dziennym świń rasy puławska $(p<0,01)$, ze zużyciem paszy na $1 \mathrm{~kg}$ przyrostu w grupie łączącej 6 ras $(p<0,05)$ i z wiekiem $w$ dniu uboju, a także $z$ liczbą dni tuczu w czasie testu świń rasy puławska $(p<0,01)$ i w grupie łączącej 6 ras (odpowiednio $\mathrm{p}<0,01 \mathrm{i} p<0,05$ ). Uzyskane wyniki wskazują, że gen PLIN2 jest bardziej powiązany z cechami wzrostu świń niż gen FTO; wymaga to jednak kolejnych analiz i wyjaśnienia.
\end{abstract}

Słowa kluczowe: FTO, PLIN2, polimorfizm, cechy wzrostu, świnie. 
